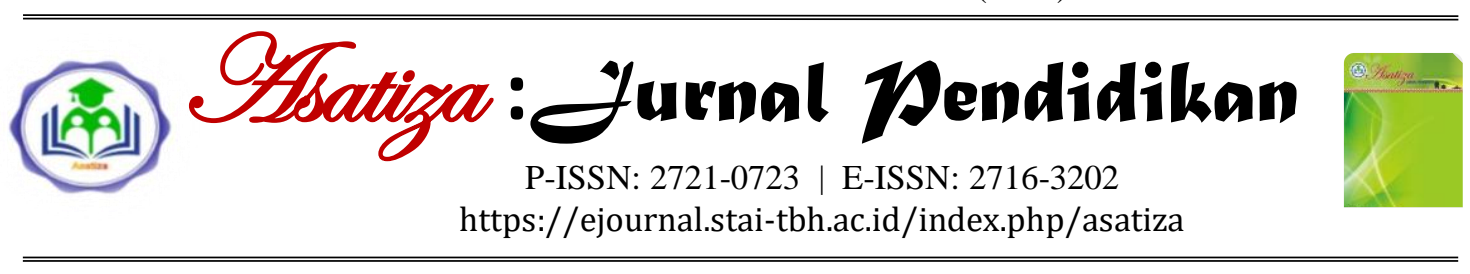

\title{
Pengintegrasian Nilai-Nilai ke-Islaman dengan Pembelajaran Bahasa Jawa
}

\author{
Muhamad Farizal $^{1 *}$, Muqowim ${ }^{2}$ \\ ${ }^{1,2}$ Pascasarjana, Universitas Islam Negeri Sunan Kalijaga, Yogyakarta, Indonesia
}

\begin{tabular}{|c|c|}
\hline $\begin{array}{l}\text { INFORM } \\
\text { ARTIKE }\end{array}$ & \\
\hline Histori A & tikel: \\
\hline Diterima & $: 25 / 01 / 2021$ \\
\hline Direvisi & $: 05 / 04 / 2021$ \\
\hline Disetujui & $: 04 / 05 / 2021$ \\
\hline Diterbitka & : 24/05/2021 \\
\hline
\end{tabular}

\section{Keywords:}

Integrasi, Nilai-Nilai

Ke-Islaman, Bahasa

Jawa

\section{Kata Kunci:}

Integration, Islamic

Values, Javanese

\section{DOI: \\ https://doi.org/10.46963/ asatiza.v2i2.296}

*Correspondence

Author:

muhammadfarizal86@g mail.com

\begin{abstract}
The purpose of this study was to determine the process and the integration of Islamic values into Javanese language learning. This research method was carried out qualitatively descriptive. This study described how the teacher combines Islamic values with Javanese language learning for grade V students. The subjects of this study were students and teachers of MI Ma'arif Darussalam. The data collection technique used was unstructured interviews. Observations are made by observing teacher activities in the classroom and outside the classroom in teaching activities that are familiar with the student's personality. Documentation was done by finding and collecting documents related to the teaching plan to get data about the habits of these characters. Data analysis techniques using data reduction, data display, and conclusions. The result of this research is that the integration of Islamic values with Javanese language learning carried out by the teacher is already at a good stage and has been implemented in the Madrasah Ibtidaiyah.
\end{abstract}

\begin{abstract}
Abstrak
Tujuan penelitian ini adalah untuk mengetahui proses dan penerapan pengintegrasian nilai-nilai Islam ke dalam pembelajaran bahasa Jawa. Metode penelitian ini dilakukan secara kualitatif deskriptif. Penelitian ini mendeskripsikan bagaimana guru memadukan nilai-nilai Islam dengan pembelajaran bahasa Jawa pada siswa kelas V. Subjek penelitian ini adalah siswa dan guru MI Ma'arif Darussalam. Teknik pengumpulan data yang digunakan adalah wawancara tidak terstruktur. Observasi dilakukan dengan mengamati aktivitas guru di dalam kelas dan di luar kelas dalam kegiatan mengajar yang akrab dengan kepribadian siswa. Dokumentasi dilakukan dengan mencari dan mengumpulkan dokumen yang berkaitan dengan rencana pengajaran untuk mendapatkan data tentang kebiasaan karakter tersebut. Teknik analisis data menggunakan reduksi data, tampilan data dan kesimpulan. Hasil dari penelitian ini adalah bahwa integrasi nilai-nilai ke-Islaman dengan pembelajaran bahasa Jawa yang dilakukan oleh guru sudah pada tahap yang baik dan sudah diterapkan di Madrasah Ibtidaiyah tersebut.
\end{abstract}

\section{Cara mensitasi artikel:}

Farizal, M., \& Muqowim, M. (2021). Pengintegrasian Nilai-Nilai ke-Islaman dengan Pembelajaran Bahasa Jawa pada Siswa Madrasah Ibtidaiyah. Asatiza: Jurnal Pendidikan, 2(2), 77-88. https://doi.org/10.46963/asatiza.v2i2.296

\section{PENDAHULUAN}

Dalam perkembangan dunia pendidikan yang ada, saat ini pendekatan pembelajaran merupakan sesuatu yang mempunyai pengaruh besar yang sangat penting (Nurdyansyah, 2015). Hal tersebut sebagaimana dalam penjelasan UU pasal 1 ayat 2 No. 20 Tahun 2003 yang menjelaskan bahwa: Pendidikan Nasional ialah pendidikan yang berlandaskan 
Pancasila dan Undang-Undang Dasar yang mengacu pada nilai-nilai religius, budaya bangsa Indonesia dan menjawab kebutuhan masa. Melihat dari pendidikan nasional dengan kebudayaan nasional yang ada dalam pendidikan yaitu dengan adanya kurikulum pembelajaran bahasa Jawa.

Selain itu terdapat dua landasan yang utama dalam rangka mengintegrasikan nilai-nilai agama ke dalam pendidikan nasional yang tercantum dalam UUD 1945 (versi Amandemen) Pasal 31 ayat 3 dan 5. (Rofi'ah, t.t., hlm. 138) Adapun pada ayat 3 menyebutkan, "Pemerintah mengusahakan dan menyelenggarakan satu sistem pendidikan nasional yang meningkatkan keimanan dan ketakwaan serta akhlak mulia dalam rangka mencerdaskan kehidupan bangsa yang diatur dalam undang-undang." Serta pada ayat 5 yang menyebutkan, "Pemerintah memajukan ilmu pengetahuan dan teknologi dengan menjunjung tinggi nilai-nilai agama dan persatuan bangsa untuk kemajuan peradaban serta kesejahteraan umat manusia." Dari kedua undang-undang tersebut dapat kita pahami bahwa pengintegrasian nilai-nilai agama dalam pembelajaran merupakan suatu amanah konstitusi yang memiliki arti bahwa tujuan pendidikan di Indonesia tidak hanya mengembangkan potensi dan mencerdaskan saja, akan tetapi memiliki tujuan untuk membentuk manusia yang memiliki karakter agamis yang baik.

Nurdyansyah menyebutkan "The education world must innovate in a whole. It means that all the devices in education system have its role and be the factors which take the important effect in successful of education system". (N. Nurdyansyah dkk., 2017)

Tentunya dalam kegiatan pembelajaran tak hanya peserta didik dan pendidik yang terlibat, namun juga melibatkan banyak pihak. Karena pada dasarnya pendidikan memiliki hakikat belajar bahwa dalam suatu proses pengarahan dan pembelajaran guna tercapainya sebuah tujuan tertentu dengan pengalaman kreatif dan terukur. Dengan adanya tujuan yang ingin dicapai tersebut tentunya diperlukan suatu bahan ajar. Bahan ajar itu sendiri merupakan suatu alat dan bahan pembelajaran guna tercapainya kapabilitas yang sudah ditetapkan.

Namun dunia pendidikan yang ada pada saat ini sedang menghadapi di mana terdapat macam-macam permasalahan yang kompleks sehingga membutuhkan perhatian khusus dari kita semuanya terutama terhadap peserta didik. Di mana di zaman modern ini ilmu pengetahuan dan teknologi berkembang secara tak langsung memiliki dampak terhadap perkembangan dan proses pembelajaran pada siswa. Dengan perkembangan ilmu pengetahuan yang mana, peserta didik semakin lama akan meninggalkan kebudayaan nasional yang ada pada tujuan pendidikan nasional itu sendiri. Keprihatinan terhadap perkembangan IPTEK ini sendiri terdapat pada krisis moral yang menyebar luas terhadap sikap dan perilaku seseorang menjadi menurun dan cenderung buruk. Salah satunya adalah menurunnya norma kehidupan, baik norma sosial maupun norma moral. (Baharudin, 2009) 
Berkaitan dengan norma sosial, salah satu dampak dari perkembangan IPTEK yang ada ialah semakin menurunnya komunikasi yang baik diantara sesama makhluk sosial. Mereka cenderung acuh dan tidak peduli satu sama lain ketika mendapatkan suatu masalah. Untuk itu dalam proses pembelajaran didunia pendidikan dibutuhkan suatu pembelajaran yang dapat menurunkan masalah sosial dan agama serta kebudayaan yang ada dengan penerapan pembelajaran bahasa Jawa dengan harapan mereka para peserta didik tidak akan melupakan dan meninggalkan kebudayaan yang ada.

Sistem komunikasi yang efektif antara seseorang dengan seorang lainnya adalah melalui sarana bahasa. Melalui tatanan dan penempatan penggunaan bahasa komunikasi yang tepat, Kepribadian orang tersebut bisa tercermin kan melalui pesan yang tercantum pada saat ia menyampaikannya. Dengan penggunaan sarana bahasa yang baik maka nantinya akan menghasilkan proses komunikasi dan berhubungan sosial dengan baik serta damai. Penggunaan bahasa sudah semestinya di taati menurut kaidahnya. Kebudayaan Jawa tentunya selalu berdasarkan atas etika jawa yang mempunyai nilai-nilai baik sesuai maupun tidak sesuai jika dijalankan pada hidup sehari-hari (Yulianti dkk., 2018).

Menurut Digdaya dalam (Purwadi, 2011)Dalam penerapan dan penggunaan bahasa Jawa dilakukan dengan tidak tepat pada tatarannya, maka nantinya akan menimbulkan suatu pergaulan yang tidak baik, tidak serasi dan mengganggu satu sama lain. Tingkatan bahasa Jawa yang digunakan dalam sebuah pergaulan disebut unggah-ungguh. Clifford Geertz dalam (Setyanto dkk., 2015) juga mengungkapkan bahwa unggah-ungguh disebut sebagai adapt asor, yakni sikap rendah hati, santun, perilaku baik, serta wajib diperlihatkan sama semua orang yang setingkat.

Namun pada kenyataan ini bahwa penggunaan Bahasa yang dilakukan sering kali tidak diimbangi dengan karakterkarakter nilai keislaman. Makin hari makin dikit pula masyarakat pada umunya yang hendak menggunakan bahasa Jawa dalam kehidupan sehari-hari terutama di lingkungan yang lebih luas. Hal tersebut pun juga berdampak pada penanaman karakteristik Islam pada diri manusia. Karena itu, perkembangan karakteristik Islam sangatlah dibutuhkan guna membentuk penerus yang lebih sopan saat bertutur kata bahasa Jawa pada khususnya dan berakhlakul karimah. Sebagaimana dalam sabda Rasulullah SAW :(Sani \& Kadri, 2016)

"Sesungguhnya aku diutus hanyalah untuk menyempurnakan akhlak yang mulia" (H.R. Ahmad)

Firman Allah SWT :

"Dan sesungguhnya kau (Muhammad) benar-benar berakhlak yang agung" (Q.S Al-Qalam ayat 4)

Dengan demikian maka, pembelajaran bahasa nantinya diharapkan mampu untuk membuat peserta didik lebih mengenali dirinya, budayanya dan budaya orang lain. Penggunaan bahasa juga menjadi suatu faktor penting dalam pembentukan karakter setiap orang. Bahasa Jawa sebagai bahasa yang memiliki suatu karakter yang disebut 
ngoko dan krama, merupakan suatu bahasa yang dianggap tepat jika nantinya diintegrasikan dengan nilai-nilai karakter keislaman pada setiap peserta didik dalam proses pembelajaran dikelas.

Madrasah Ibtidaiyah sebagai lembaga pendidikan yang berada pada naungan Kementerian Agama memiliki kurikulum yang tentunya berkaitan dengan pendidikan agama Islam yang tinggi. Sebagai lembaga pendidikan yang berkarakter Islami tentunya memiliki peranan penting dalam mengintegrasikan antara pembelajaran umum dengan pembelajaran yang berkarakter Islam. Peran seorang guru dalam hal ini menjadi sangat penting guna menerapkan karakter keislaman dalam pembelajarannya. Dengan melihat bagaimana pelaksanaan, strategi dan media dalam penerapan pembelajaran bahasa Jawa dengan pengintegrasian. Sehingga peneliti tertarik untuk melihat bagaimana penerapan yang dilakukan guru dan siswa di MI Ma'arif Darussalam Klaten dalam mengintegrasikan antara nilai-nilai keislaman dengan pembelajaran bahasa Jawa yang ada.

\section{METODE}

Penelitian ini menggunakan metode penelitian dalam pendekatan kualitatif deskriptif (Sanjaya, 2013). Yaitu dengan mendeskripsikan mengenai bagaimana upaya guru dalam mengintegrasikan nilainilai keislaman dengan pembelajaran Bahasa Jawa terhadap peserta didik kelas V MI Ma'arif Darussalam, Plaosan, Klaten, Jawa Tengah. Adapun subyek pada penelitian ini adalah siswa dan guru MI Ma'arif Darussalam. Teknik pengumpulan data yang dipakai adalah wawancara, observasi dan dokumentasi. Wawancara memakai teknik wawancara tidak terstruktur. Kemudian teknik observasinya yaitu dengan mengamati kegiatan guru saat melatih karakteristik terhadap siswa pada proses pembelajaran di dalam kelas ataupun di luar kelas. Teknik dokumentasi yang dilakukan dengan mencari dan mengumpulkan datadata terkait dengan rencana pengajaran, dan rencana pengajaran ini secara khusus direncanakan untuk mendapatkan data tentang kebiasaan karakter tersebut. Adapun analisis data yang dipakai yaitu dengan teknik reduksi data, penyajian data serta penarikan kesimpulan.

\section{HASIL DAN PEMBAHASAN}

\section{Bahasa Jawa dalam Pembelajaran di Sekolah}

Penggunaan bahasa Jawa adalah hal penting untuk digunakan pada tiap-tiap masyarakat khususnya daerah Jawa Tengah dan Jawa Timur. Masyarakat Jawa memakai bahasa Jawa sebagai bahasa yang digunakan pada lingkup kehidupan sehari-hari. Pada tentunya orang Jawa diharuskan memakai bahasa Jawa yang benar disesuaikan pada derajat, hak dan kewajiban, kehormatan serta usianya. Pada tataran pemakaian bahasa Jawa bisa disebut dengan unggah-ungguh (Purwadi, 2011).

Menurut Saputro dalam (Rochayanti dkk., 2014) sebutan kata atau bahasa saat ditampilkan terhadap orang dinamakan unggah-ungguh, yang dibagi atas tiga bagian yakni bahasa kroma, bahasa ngoko, dan bahasa madya. Bahasa-bahasa ini mengandung arti serta moral yang sangat berarti. Rochayanti juga mencontohkan bahwa bahasa Jawa yang biasa dipakai 
oleh orang-orang Jawa yaitu bahasa Jawa Ngoko yang artinya bahasa Jawa kasar, akan tetapi jika berkomunikasi dengan orang yang memiliki status umur lebih tua, masyarakat sering menggunakan bahasa Jawa kromo, baik itu kromo madya maupun kromo inggil. Penggunaan bahasa yang berbeda-beda tentunya memberikan keberagaman yang luas terhadap bahasa Jawa yang ada (Rochayanti dkk., 2014).

Sabdawara dalam (Setyanto dkk., 2015) menyebutkan bahasa Jawa bisa dipakai sebagai tempat pembentukan karakter dan tingkah laku, karena memiliki perbendaharaan kata yang kaya dan lengkap sebagai bahasa yang meliputi: kegunaan, peraturan, serta hukum bahasa, perubahan dan ukuran bahasa, moral serta nilai budaya luhur dan ke semuanya kedudukan dan fungsi. Fungsi bahasa Jawa sendiri ialah untuk komunikasi dan berfungsi penting dalam memperkenalkan nilai-nilai luhur dan sopan santun dengan mengidentifikasi batasan serta menciptakan jiwa bertanggungjawab. Nilai sopan tersebut bisa menumbuhkan kepribadian orang.

Berhubungan dengan pembelajaran, bahasa Jawa harus diartikan dengan dasar semua tanda-tanda yang memiliki ruang lingkup kehidupan bahasa Jawa, yaitu: tanda-tanda sosial dan pribadi, memiliki peran simbiolik dan sistematik, dan terintegratif serta progresif. Berkaitan dengan gejala sosial, bahwa bahasa Jawa itu sendiri ialah suatu wahana interaksi, terjalinnya kerja sama, dan membentuk komunitas bagi masyarakat penggunanya. Berikutnya sebagai gejala personal, bahwa bahasa Jawa ialah tempat dalam pembentukan serta pengungkapan suatu ide, rasa, serta sebagai wujud dalam menghargai kebenaran suatu nilai-nilai yang baik secara reseptif ataupun produktif. Selanjutnya sebagai gejala simbolik, bahwa bahasa Jawa merupakan suatu sistem lambang yang dapat menggambarkan konsepsi dan maksud tertentu di luar wujud konkret yang terdengar maupun teramati. Sebagai gejala sistemis, yaitu sebagai suatu sistem lambang dalam bahasa Jawa memiliki kaidah yang merupakan sistem abstrak yang tidak begitu saja dapat dihayati tanpa didahului pengalaman menggunakannya. Dan yang terakhir sebagai suatu gejala integratif dan progresif, bahasa Jawa ini mempunyai elemen yang utuh secara terus menerus berkembang sesuai dalam penggunaannya pada saat berkomunikasi (Sri Maruti, 2015)

Berdasarkan dari pemaknaan tersebut, dijelaskan bahwa bahasa Jawa sudah semestinya dipandang sebagai satu Kesatuan antara sistem dan aturan, serta fungsi dan realitasnya dalam kehidupan sosial masyarakat. Sebagai satu kesatuan bentuk pembelajaran bahasa Jawa perlu dilakukan sesuai dengan pengalaman bahasa yang ditangkap oleh peserta didik pada kehidupan sehari-hari, serta belajar tidak lepas dari sistem pemahaman dan kaidah, dalam persaingan hidup, penguasaan kemampuan ekspresi bahasa dan bahasa yang digunakan dalam menyelesaikan berbagai masalah. Bentuk dan kemampuan berkaitan dengan penggunaan dan kemampuan bahasa secara keseluruhan.

Menurut Endang, pemahaman kaidah bahasa Jawa tidak mengikuti dari wujud penggunaan bahasa Jawa baik lisan 
maupun tertulis. Kaidah bahasa Jawa bukan suatu konsep artifisial yang terbentuk dari tata bahasa tertentu, akan tetapi perwujudannya dalam pemakaian. Sebagai perwujudan dari pemakaian, maka kaidah bahasa Jawa meliputi kemajemukan dan kedinamisan. Kedinamisan dan kemajemukan itu sebagaimana muncul dalam peristiwa komunikasi, orang tidak hanya sekedar menangkap bunyi dan deretan kata, serta hubungan sistematis tersebut secara terpisah-pisah, tetapi merupakan suatu kesatuan yang memiliki makna berdasarkan ciri konteks yang menyertainya. Atas pemahaman hal tersebut, akan terwujud apabila pembelajaran memiliki potensi untuk menggunakan dalam tindak berbahasa Jawa secara tepat dan kreatif (Sri Maruti, 2015).

Berdasarkan hal di atas, maka pemahaman tata bunyi, tata kalimat, tata makna, dan tata penggunaan bahasa Jawa tidak dibentuk dan dilangsungkan secara terpisah, tetapi utuh dan terpadu. Dengan demikian, pengetahuan tata bunyi, tata kata, tata kalimat, tata makna, dan tata penggunaan bahasa Jawa tidak hanya menjadi endapan dalam pemikiran siswa, tetapi juga dapat dimanfaatkan secara aktual dalam mereka berkomunikasi. Wujud pembelajaran semacam itu dapat diperoleh oleh siswa melalui penghayatan secara nyata penggunaan bahasa Jawa, bukan hanya sekedar menghafal bunyi dan kata atau kalimat yang tidak memiliki fungsional dan relevansional dengan kenyataan penggunaan bahasa Jawa.
Dari pandangan di atas, maka tata bahasa Jawa yang diajarkan di sekolah, seperti pendapat Celce-Murcia dalam Endang, menyebutkan bahwa tata bahasa yang dapat mengintegrasikan antara konsep nasional (kebermaknaan) dan fungsional, atau yang memenuhi kriteria deskriptif, psikolinguistik, estetik, dan etis-sosial. Tata bahasa Jawa yang demikian itu tidak memisah belahkan antara bahasa ngoko dan kromo. Pengajaran bahasa Jawa sendiri merupakan sistem sikap terhadap bahasa Jawa berfokus pada kontinuitas dan keutuhan materi pembelajaran, hasil belajar dan sistem pengajaran.

Sebagai sistem pengajaran, bahasa Jawa perlu dimaknai sebagai salah satu bentuk pengajaran bahasa, tidak hanya memandang bahasa Jawa dari perspektif struktur bahasa Jawa, tetapi juga dari segi fungsi komunikasi yang dibutuhkannya, dapat digunakan dan dimainkan dengan pembelajaran. Berdasarkan pengertian tersebut, faktor-faktor yang berhubungan dengan sistem pengajaran bahasa Jawa antara lain mata kuliah, guru, peserta didik atau siswa.

Kurikulum bahasa Jawa yang perlu diselenggarakan secara nasional dan fungsional perlu memperhatikan hal-hal sebagai berikut:

1. Perspektif bahasa Jawa, baik secara hakiki dalam pembelajaran bahasa dan sebagai bentuk bahasa yang mengenal berbagai ragam, maupun sebagai salah satu bahasa dalam masyarakat multilingual di Indonesia atau sebagai bahasa daerah serta kedudukan dan fungsinya. 
2. Konsepsi belajar bahasa, yang memiliki arti belajar bahasa akan bermanfaat bagi siswa bila relevan dengan nilai aktualisasinya bagi siswa, ada dalam keutuhan, bermakna, dan tidak dilepaskan dari konteks maupun pengalaman konkret dalam penggunaan bahasa

3. Metode yang merujuk pada cara penyiapan bahan pembelajaran.

4. Penilaian, yang tertuju pada hasil perkembangan kemampuan berbahasa siswa.

Tentunya dalam proses pembelajaran bahasa Jawa di suatu lembaga pendidikan harus melihat dari perspektif bahasa Jawa dalam kesemestaannya. Bahasa Jawa dalam lingkup kesemestaannya sudah memiliki usia yang tua. Untuk itu penting sekali jika pembelajaran bahasa Jawa terus dilaksanakan dan dengan mengintegrasikannya ke dalam pengajaran nilai-nilai lainnya.

Pengintegrasian nilai-nilai Ke-Islaman pada Pembelajaran Bahasa Jawa Siswa Kelas V

Berdasarkan hasil observasi di MI Ma'arif Darussalam yang peneliti lakukan dengan melakukan wawancara dengan Ibu Dian selaku Kepala Madrasah, beliau menyebutkan bahwa:

"MI Ma'arif Darussalam ini memiliki program pengintergasian antara materi pembelajaran bahasa Jawa dengan materi agama Islam pada kelas tinggi. Pengintegrasian dilakukan dengan menjadikan Al-Quran dan Hadis sebagai sumber ilmu pengetahuan serta menelusuri ayat-ayat Al-Quran yang berkaitan dengan nilai-nilai karakter dalam pembelajaran bahasa Jawa."

Adapun selain dari hasil observasi peneliti juga melakukan wawancara dan dokumentasi pada penelitian ini terhadap guru pada mata pelajaran bahasa Jawa yaitu Ibu Riris melalui media sosial WhatsApp, bahwasanya dalam mengintegrasikan nilai-nilai keislaman dengan pembelajaran bahasa Jawa ialah:

1. Tentang bagaimana proses pembelajaran yang berlangsung di kelas, beliau mengatakan bahwa:

"Strategi pengajaran yang saya lakukan ialah pertama Kegiatan awal, melalui salam dan doa, kemudian menanyakan beberapa materi sebelumnya atau pekerjaan rumah sebelumnya. Pembelajaran juga diawali dengan wawasan yang bisa mencuri minat peserta didik, khususnya terkait dengan bahan agama". Kemudian kegiatan inti, menjelaskan materi ajar atau mendiskusikan masalah. Kegiatan keagamaan terutama dilakukan dalam kegiatan inti. Kegiatan penutupan dilakukan dengan melakukan post test, menyerahkan pekerjaan rumah (jika ada), serta menarik kesimpulan atas bahan yang diserahkan yang terkandung dalam penilaian religious. Lalu diakhiri dengn doa serta salam ". 


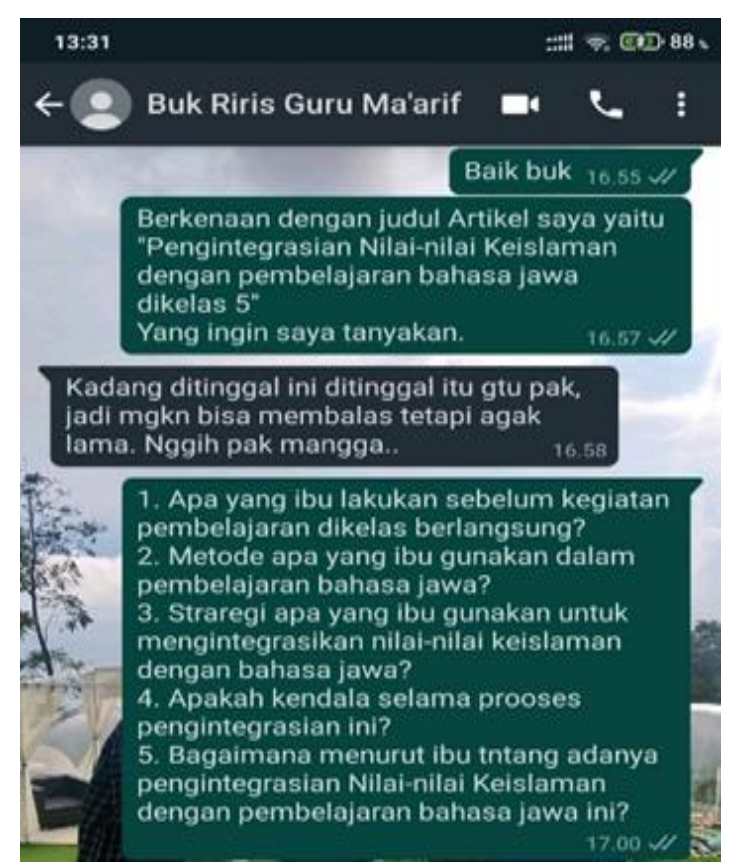

Dokumentasi wawancara via WhatsApp

Menurut strategi yang

dikembangkan oleh Deni Kurniawan, strategi tersebut menyatakan: Pada tahap awal ada 3 aktivitas: (1) pendeskripsian isi mata kuliah secara singkat; (2) mendeskripsikan secara teoritis dan praktis konten pembelajaran baru dan materi masa lalu, siswa Relevansi pengalaman dan potensi penggunaan; (3) menjelaskan maksud pembelajaran yang hendak diraih..

Pada bagian inti ini terdapat beberapa langkah yaitu: (1) mendeskripsikan tema: (2) menjelaskan deskripsi melalui contoh; (3) membuat pelatihan guna meningkatkan penerimaan peserta didik. Bagian akhir yakni meliputi 2 langkah yaitu merangkum bahan ajar, melakukan ujian, serta melakukan tindak lanjut (Kurniawan, 2013).

Tahapan-tahapan yang dilakukan dalam kegiatan belajar menunjukkan keterpaduan bahan ajar agama pada kegiatan belajar. Sifat pengintegrasian bagi pembelajaran bahasa Jawa pada penilaian keislaman dalam aktivitas sehari-hari sesudah pada tahap yang baik. Seperti contohnya guru mengintegrasikan pembelajaran bahasa Jawa dengan memberikan soal-soal untuk latihan dengan isi materi yang berkaitan dengan nilai-nilai ke-Islaman dan dikaitkan dengan kebudayaan yang ada.

2. Selanjutnya mengenai metode yang di gunakan dalam pembelajaran bahasa Jawa ini, menyebutkan bahwa:

"Dalam melaksanakan pembelajaran ini saya menggunakan metode ceramah dan praktik. Adapun strategi yang saya pilih adalah dengan menggunakan pendekatan kooperatif. Dengan demikian dapat mengajarkan pada anak keterampilan sosial dalam pemecahan masalah"

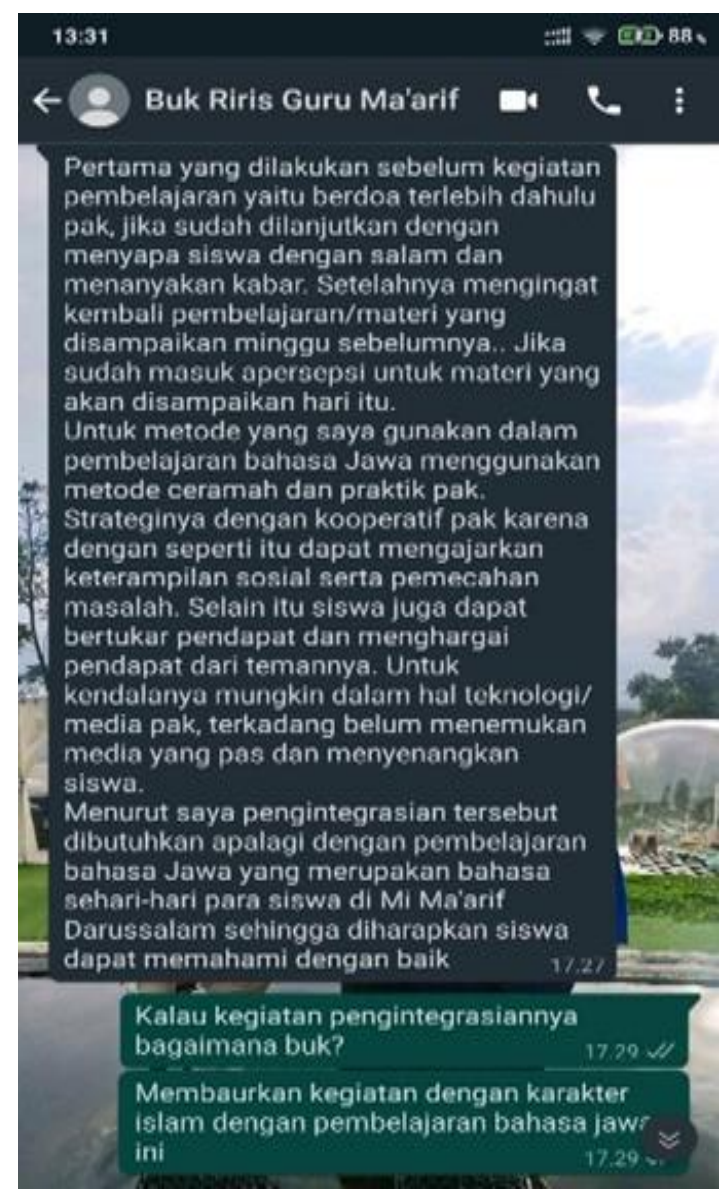

Dokumentasi Wawancara via WhatsApp 
Atas dasar cara dan langkah yang dipakai saat berlangsungnya penelitian ini, menghasilkan: (1) guru bahasa jawa harus membuat rancangan pada kegiatan belajar integritas bahan ajar agama yakni dengan membuat RPP serta menyusun bahan ajarnya. menyiapkan alat untuk proses belajar-mengajar. Menurut Nana Sudjana bahwa pada intinya pertanyaan yang wajib diberi jawaban pada rancangan kegiatan belajar-mengajar ialah tujuan kegiatan pembelajaran, bahan ajar/materi, alat yang dipakai saat kegiatan pembelajaran. Dan evaluasi kegiatan belajar-mengajar (Sudjana, 2013). RPP merupakan komponen inti yang wajib disiapkan ketika merencanakan kegiatan belajar yang integrasi antar materi bahasa Jawa dan materi agama. Saat berlangsungnya kegiatan ini, RPP yang sudah dirancang oleh para pendidik ternyata secara jelas belum memperlihatkan keterpaduan bahan ajar agama pada kegiatan pembelajaran. Rencana kurikulum baru yang dirancang ialah rencana kurikulum berkarakteristik yang belum terintegrasi dengan materi agama.

3. Sedangkan untuk metode dan tahapan pengintegrasian ini ialah:

"Memberikan pelatihan-pelatihan berupa soal yang dipilih dari tema dan topik pembelajaran bahasa Jawa yang didalamnya tercantum nama-nama islami, juga dengan tempat-tempat yang berhubungan dengan tempat islami. Selain itu dipilih dari materi kebudayaan ialah dengan mengenalkan budaya Jawa yang berkaitan dengan nilai-nilai Islam yaitu kegiatan sekaten. Sekaten ini adalah aktivitas saat memperingati hari lahir Nabi Muhammad SAW, yang dilaksanakan 7 hari 7 malam di Keraton Yogyakarta dengan membawa Gunungan yang berbentuk kerucut sebagai arti nikmat syukur atas kesejahteraan yang diberikan Allah SWT".

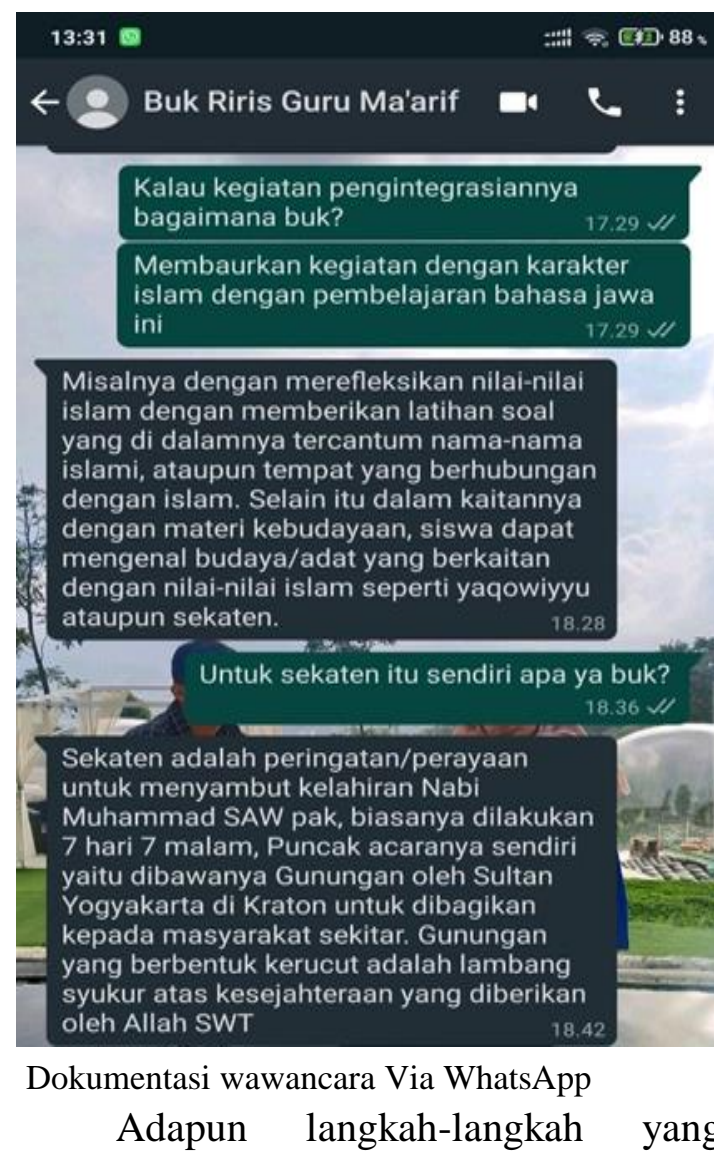
digunakan untuk mengintegrasikan pembelajaran bahasa Jawa dengan keislaman adalah sebagai berikut:(Zain \& Vebrianto, 2017)

a. Menentukan judul/topik yang hendak dipelajari. Topiknya wajib jelas supaya siswa bisa mempelajari segala rencana terkait.

b. Mengidentifikasi rencana apa yang hendak dimajukan, lalu buat daftar. rencana inilah yang menjadi kunci awal untuk menetapkan aktivitas saat pembelajaran. Rencana tersebut harus didefinisikan secara langsung pada subjeknya. 
c. Tentukan aktivitas yang akan dilakukan untuk menyelidiki konsep yang terdaftar. Memastikan setiap rencana yang diamati membutuhkan satu/lebih aktivitas terkait topik.

d. Identifikasi bidang penelitian atau topik yang terkait dengan konsep tertentu. Artinya dalam proses penyorotan konsep, berbagai bidang penelitian atau bidang keilmuan telah terintegrasi.

e. Review kegiatan dan bidang penelitian yang berkaitan dengan pembelajaran terintegrasi. Tujuan dari tinjauan tersebut adalah untuk menilai keefektifan penggunaan bidang penelitian tertentu atau disiplin ilmu yang dipilih.

f. Mengatur materi supaya memudahkan distribusi atau penggunaan dalam kegiatan yang dilakukan secara individu atau kelompok.

g. Menetapkan bagian-bagian aktivitas pada pelaksanaan kelas, sebaiknya dimulai dari urutan yang paling sederhana atau paling mudah atau yang sudah diselesaikan oleh siswa.

h. Melakukan diskusi lanjutan. Supaya potensi peserta didik bisa ditingkatkan saat menjelaskan sesuatu yang sudah dilakukannya serta menarik kesimpulan.

Keberhasilan penggunaan metode, merupakan suatu keberhasilan kegiatan pembelajaran pada akhirnya sangat menentukan kualitas pendidikan. Metode belajar yang diterapkan wajib disesuaikan pada asas-asas berikut: (!) berdasarkan pandangan bahwasanya setiap manusia yang lahir pasti sudah ada kemampuan alam yang secara aktif berkembang sesuai dengan lingkungannya masing-masing; (2) langkah pembelajaran atas dasar pada karakter sosial sipil, yaitu masyarakat dapat dengan gratis mengungkapkan rasa takutnya. Ketiga, metode pembelajaran didasarkan pada prinsip pembelajaran kemampuan. Bertujuan untuk menguasai pengetahuan, keterampilan, sikap, wawasan dan penerapannya sesuai standar atau tujuan pembelajaran (Munjin dkk., 2009).

Prinsip metodologis digunakan sebagai dasar dalam perumusan langkahlangkah yang bisa mempercepat tercapainya tujuan pendidikan berdasarkan informasi dari Alquran. Dalam hal ini, terdapat bagian-bagian yaitu:(Kholidah, 2015):

a. Kebaikan dan kelembutan (Q.S. Ali Imran:159)

b. Berikan suasana yang menyenangkan (Q.S. Al Baqarah 25)

c. Motivasi untuk mewujudkan potensi yang dimiliki (Q.S. Al A-raf:179)

d. Berikan pengetahuan yang baru (Q.S. Al Baqarah 164)

e. Berikan contoh perilaku yang baik (Q.S. Al Ahzab 21).

Berdasarkan atas prinsip-prinsip di atas dan mengambil langkah-langkah untuk memilih dan menentukan langkah belajar. Terdapat beberapa langkah belajar yang bisa digunakan untuk integrasikan penilaian ketuhanan dan manusia antara lain deduksi, induksi, dan pemecahan masalah. Metode deduktif menyajikan nilai kebenaran melalui keterampilan mendeskripsikan konsep kebenaran 
sehingga siswa dapat memahaminya yang dilandasi kebenaran sebagai konsep yang memiliki nilai yang baik, kemudian dihubungkan dengan berbagai situasi dan permasalahan pada kehidupan sehari-hari. Disaat yang sama, metode induksi, yaitu nilai pengajaran, memulainya pada pengenalan problem dalam hidup seharihari. Selain itu, dalam arti tertentu, kearifan pada dasarnya adalah mengenai penilaian pada peristiwa yang nyata dalam kehidupan.

Tahap pemecahan masalah ialah tahap belajar dengan aktivitas pemecahan masalah. Pada tahap pemecahan permasalahan ini, siswa diberi peluang untuk melakukan identifikasi suatu permasalahan pada distorsi penilaian sosial yang akan dipecahkan, menganalisis sumber masalah serta mencari tahu penyebab masalah, mencari jalan pemecahan masalah, mengetes kelemahan dan kelebihan masing-masing jalan penyelesaian. Solusi dan evaluasi hasilnya. mencapai (Munjin dkk., 2009).

Dengan demikian, melalui pemilihan organisasi materi dan metode, pengintegrasian penilaian Islam pada pembelajaran bahasa Jawa menjadi model integrasi yang dapat diterapkan dalam mentransformasikan nilai-nilai Islam. Integrasi ini merupakan konsep dan model teknis yang dapat diterapkan, yang menyesuaikan dengan karakteristik unik pendidikan agama Islam, yang tak hanya menekankan pada segi kognitif, emosional dan psikomotorik, tetapi juga pada aspek spiritual.

\section{SIMPULAN}

Berdasarkan hasil pembahasan dapat diambil kesimpulan bahwasanya guru mata pelajaran Bahasa Jawa menyusun RPP, buku teks / bahan ajar, dan media pembelajaran dalam proses perencanaan pemaduan materi agama. Pada perencanaan RPP terintegrasi, sebaiknya ditetapkan terlebih dahulu topik pada mata pelajaran bahasa Jawa yang akan diintegrasikan dengan materi keislaman, kemudian tentukan indikator dan tujuan yang hendak dicapai. Modul pembelajaran yang dipakai bahasa Jawa memiliki materi agama yang terintegrasi.

Kegiatan pembelajarannya sudah terintegrasi antar materi bahasa Jawa dan materi religi. Integrasi biasanya dilaksanakan tidak sengaja, dan sifat tema utama dipertahankan. Dengan demikian, integrasi materi keagamaan dapat diklasifikasikan sebagai topik bahasa Jawa, termasuk model terkait (model koneksi). Adapun langkah-langkah yang perlu dilakukan guru dalam melaksanakan pembelajaran bahasa Jawa yang terintegrasi dengan nilai keislaman yaitu dengan menentukan tema topik, menentukan konsep-konsep yang akan dikembangkan, menentukan kegiatan yang akan dilaksanakan, dan memilih materi dan menelusuri ayat-ayat Alquran yang berkaitan dengan materi tersebut.

\section{REFERENSI}

Baharudin. (2009). Pendidikan dan Psikologi Perkembangan. Yogyakarta. Ar Ruzz Media.

Kholidah, L. N. (2015). Pola Integrasi Nilai-Nilai Keislaman dalam Pembelajaran Pendidikan Agama Islam pada Lembaga Pendidikan. AtTa'dib, 10(2). 
Kurniawan, D. (2013). Pembelajaran Berbasis Teknologi Informasi dan Komunikasi. Rajawali Press.

Munjin, A., Nasih, \& Nur Kholidah, L. (2009). Metode dan Teknik Pembelajaran Pendidikan Agama Islam. Refika Adi Tama.

Nurdyansyah, M. (2015). Pendekatan Pembelajaran Saintifik. Nizamia Learning.

Nurdyansyah, N., Rais, P., \& Aini, Q. (2017). The Role of Education Technology in Mathematic of Third Grade Students in MI Ma'arif Pademonegoro Sukodono. Madrosatuna: Journal of Islamic Elementary School, 1(1), 37-46.

Purwadi, P. (2011). Etika Komunikasi dalam Budaya Jawa. Jurnal Ilmu Komunikasi Terakreditasi, 9(3), 139249.

Rochayanti, C., Pujiastuti, E. E., \& Warsiki, A. Y. N. (2014). Sosialisasi Budaya Lokal dalam Keluarga Jawa. Jurnal Ilmu Komunikasi, 10(3).

Rofi'ah, S. (2020). Integrasi Nilai-nilai Keislaman dalam Pembelajaran Sains di Madrasah Ibtidaiyah Ma'arif 01 KH. Shiddiq Jember. Childhood Education: Jurnal Pendidikan Anak Usia Dini, 1(2), 137-148. https://doi.org/https://doi.org/10.123 4/cej.v2i2.3765

Sani, R. A., \& Kadri, M. (2016). Pendidikan Karakter: Mengembangkan karakter anak yang Islami. Bumi Aksara.

Sanjaya, W. (2013). Penelitian Pendidikan: Jenis, Metode, dan Prosedur. Kencana.

Setyanto, A. E., Anggraini, L. S., \& CW, D. T. (2015). Faktor-Faktor yang Mempengaruhi Memudarnya Etika Komunikasi Masyarakat Jawa Di Kota Surakarta. Komunikasi Massa Jurnal, 121.
Sri Maruti, E. (2015). Pembelajaran Bahasa Jawa di Sekolah Dasar. Media Grafika.

Sudjana, N. (2013). Dasar-dasar Proses Belajar Mengajar. Sinar Baru.

Yulianti, I., Isnani, A., Zakkiyyah, A. L., \& Hakim, J. (2018). Penerapan Bahasa Jawa Krama Untuk Membentuk Karakter Sopan Santun Di Sekolah Dasar. Prosiding Seminar Nasional Universitas Muria Kudus 11, 160-165.

Zain, Z., \& Vebrianto, R. (2017). Integrasi keilmuan sains dan islam dalam proses pembelajaran rumpun IPA. Seminar Nasional Teknologi Informasi Komunikasi dan Industri, 703-708. 